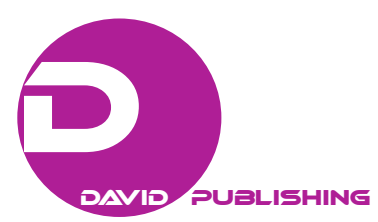

\title{
Economic Transition and Wage Differentials Between Public and Private Sectors in China*
}

\author{
Ma Xinxin \\ Hitostubashi University, Tokyo, Japan
}

\begin{abstract}
Using the reduced wage function model and decomposition methods, this paper estimated changes in wage structure and determinants of wage differentials between the public and private sectors from 1995 to 2007 in China. The major conclusions are as follows: First, with the progress of the economic system transition, wage differentials between the public sector and collective owned enterprises (COEs) decreased, but wage differentials between the public sector and foreign invested enterprises (FEs)/private enterprises (PEs) increased; second, human capital affected wage level in both the public and private sectors in 1995 and 2007, but differentials of human capital influences between the public and private sectors became narrow from 1995 to 2007; and finally, when wage differentials are decomposed into endowment effect, explained by differences in labor productivity characteristics and price effect, partly caused by institutional factors, the author observed that the former increased, while the latter decreased from 1995 to 2007. These results reveal that with the progress of market-oriented economic reform, labor productivity characteristics based on individual human capital were more highly rewarded. Results demonstrate that market mechanisms began to function and correct the distortion of wage decisions in China during the economic transition period.
\end{abstract}

Keywords: public and private sectors, wage structure, wage differentials, wage decomposition, Chinese economic transition

\section{Introduction}

Given that labor is a necessary factor of production, the wage determination mechanism attracts attention for its role in setting the price of labor properly. Neoclassical economics asserts that wages in perfectly competitive markets are decided by labor demand and supply and by the principles of utility maximization for individuals and profit maximization for firms (Piore, 1970). ${ }^{1}$ In addition, the government establishes wage

\footnotetext{
* Acknowledgments: This research was supported by JSPS (Japan Society for the Promotion Science) for its grant-in-aid for scientific research (numbers 25380297 and 25243006). I am grateful to professor Li Shi (Beijing Normal University), for providing the CHIP 1995 and CHIP 2007 data. I would like to thank professor Katsuji Nakagane (Tokyo University), professor Go Yano (Kyoto University), professor Yanrui Wu (The University of Western Australia), associate professor Kazufumi Yugami (Kobe University) for their helpful comments in 2015 First World Congress of Comparative Economics (WCCE) in Roma Tre University, 2015 International Conference "Economy Transition and Income Inequality in China" in Kyoto University, 2015 The 6th Biennial International Conference on Transition and Economic Development (TED) in Fudan University.

Ma Xinxin, Ph.D. in economics, Institute of Economic Research, Hitotsubashi University, Tokyo, Japan.

Correspondence concerning this paper should be addressed to Ma Xinxin, Institute of Economic Research, Hitotsubashi University, 2-1 Naka, Kunitachi-shi, Tokyo, 186-8603, Japan.

1 According to internal labor market theory in institutional economics, wage decisions are also related to firms' internal practices (e.g., payment and employment systems). However, it is believed that firms set wage levels by referring to market wages.
} 
policies, for example, the Minimum Wage Act, to rectify inequalities, and trade unions influence wages through collective bargaining. For more information of the Minimum Wage Act in China, please refer to Ma (2014); for the empirical studies of the effect of the Minimum Wage Act on the male and female wage levels in China, please see $\mathrm{Li}$ and $\mathrm{Ma}$ (2015). So wage policies and systems coincide with market mechanisms to determine wages.

Wage determining mechanisms in China transformed between its planned economy period (1949 to 1977) and economic transition period (post to 1978). Market mechanisms did not function during the earlier period, when the government priced both labor and capital. In planned economy period, the Chinese government enacted its united management wage policy to set wage levels and control wage growth ranges. Even as China shifted to a marketization economy, reforms to wage determination were late compared to price reforms of production and consumption goods. In addition, China's economic reform was incomplete, for example, most small state-owned enterprises (SOEs) were privatized, but the governance of large SOEs scarcely changed. Lin, Cai, and Li (1996) and Nakagane (1999) pointed out that SOEs reform was promoted after the 1990s, but it was "an incompleteness reform" (radical restructuring did not occur), because government retained ownership of large SOEs. Did ownership reforms influence wage structure of SOEs?

Then, considering the changes of wage differentials between public and private sectors under economic transition period, the ratios of average annual wages in both sectors from 1952 to 2011 are represented in Figure 1. The ratios reveal that average wages in the private sector were higher from the 1980 s to the early 1990s. However, wage differentials declined from 1993 to 2003 and the average wage levels in public sector exceeded that in private sector after 2004.

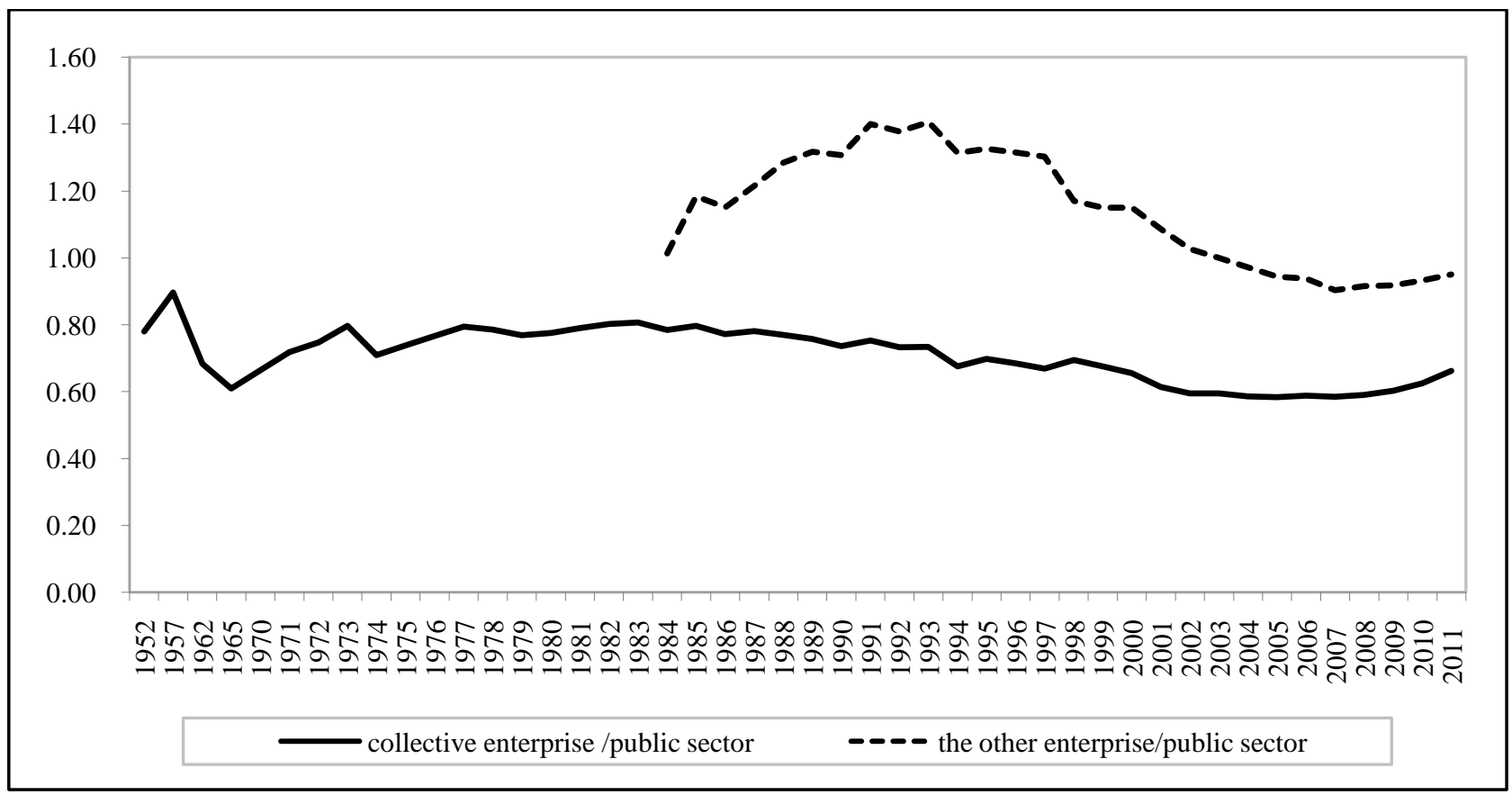

Figure 1. Wage differentials between public and private sectors. Source: Based on data from Tables 4 to 12 in Chinese Statistical Yearbook 2011. Notes. "Public sector" includes SOEs, government organizations, and units related to government organizations; "the other enterprise" includes PEs and FEs.

This paper examines changes in wage structures and determinants of wage differentials between public and private sectors during economic transition. Previous empirical studies have investigated this issue. Dong and Bowles (2002); Xing (2006); Demurger, Fournier, Li, and Wei (2007); Yin and Gan (2009); Ma (2009); 
Xing and Li (2012); and Lu, Wang, and Zhang (2012) pointed out differences in wage structures between SOEs and non-SOEs and indicated that human capital exerts greater influence on wages among non-SOEs. Chen, Demurger, and Fournier (2005); Zhang and Xue (2008); Ye, Li, and Luo (2011); Demurger, Li, and Yang (2012); and Zhang (2012) decomposed the determinants of wage differentials between public and private sectors (or between SOEs and non-SOEs) and showed that main determinants of wage differentials are individual human capital factors in relation to labor productivity.

However, these studies use annual and monthly wages as dependent variables and ignore working hours. If working hours are longer in the private sector, using annual and monthly wages rather than hourly wages (wage rates) might underestimate differentials. In addition, there was no empirical study on wage differentials from the early 1990s to the late 2000s and information is lacking about changes in wage differentials over that extended period.

In this paper, using two waves (1995 and 2007) of Chinese Household Income Project Survey data (CHIPs) in urban China, three questions are investigated. They are: (1) How large are the public-private sector wage differentials in China; (2) are there wage structure differences between the two sectors; and (3) what determinates the wage differentials between public and private sectors? Using two period survey data, changes in wage structure and determinants of wage differentials can be estimated.

The paper is structured as follows: Part 2 provides the background of changes in China's wage policies and systems during the period of economic transition; part 3 introduces the framework of the empirical analysis, including datasets and models; part 4 presents estimation results; and part 5 gives summary of conclusions and policy implications.

\section{Institutional Background: Changes in China's Wage Policy and Wage System}

To promote priority development of heavy manufacturing during the planned economy period, China's government enforced low-wage labor policies to increase employment and established a unified-management wage system in the public sector (Meng \& Kidd, 1997; Bowles \& White, 1998; Yamamoto, 2000; Marukawa, 2002; Li \& Zhao, 2003; Ma, 2006). In 1956, all self-employment sector ${ }^{2}$, private enterprises (PEs) and foreign-owned enterprises (FEs) disappeared under the "socialism remodeling" campaign enforced by the government. The entirety of the government organization, SOEs, and collectively owned enterprises (COEs) became state-owned, forming only one sector named "the public sector".

Along with the corporate governance reform, China's government reformed wage systems in 1951 and 1956 and established the grade wage system in the public sector. The government controlled wage levels and wage growth ranges. Wage determinations were essentially based on factors, such as education, occupation, and seniority (Li \& Zhao, 2003). The individual worker's labor input and productivity did not affect his wage level and promotion. Thus, the distribution of wages was equal during the early period of economic reform in the late 1970s. However, these wage policies and systems did not incentivize work efforts and both labor productivity and enterprise effectiveness were low. To solve these problems, China's government deregulated wage policies after the 1980s.

\footnotetext{
${ }^{2}$ The Urban Self-employment Management Ordinance published in August 1987 defined the self-employment sector as a privately-owned business unit that employed one or two helpers and four or five apprentices. In the other words, the self-employment sector employed fewer than eight workers. The Private Enterprise Management Ordinance published in 1988 defined a private enterprise as a privately-owned business that employed more than eight persons.
} 
Changes in wage policies and systems during the economic transition period (after 1978) can be summarized as follows.

During the 1980s, China's government rescinded policies that had been in effect more than 10 years and permitted firms to pay bonuses and piece rates. The State Council promulgated the enforcement of bonus and piece wage in 1978 and established policies concerning the upper limits of and tax rates applicable to bonuses in 1983 and 1984.

As a second major change, the government linked a firm's efficiency and profit to wage bill. In 1985 and 1986, the State Council promulgated the notification about problems of SOEs wage reform and the rules about promoting enterprise reform and enhancing enterprise vitality. They specified that government does not prescribe a unified payment system for enterprises and enterprises themselves can decide payment systems within a range of total wage accounts decided by government.

Wage policies for linking enterprise efficiency to wage bill and promoting this were published in 1987 and 1989. SOEs gained some autonomy over wage and employment decisions on the basis of hard budget constraints from the government. Overall, during the 1980s, mechanisms for deciding workers' wages became better aligned with enterprise efficiency and profit and individual human capital based on education was more highly rewarded (Meng \& Kidd, 1997).

Corporate governance reforms were ongoing throughout SOEs during the 1990s. The government published new policies extending SOEs' autonomy in determining labor employment and individual wage level, for example, in 1990 and 1992, the Chinese government promulgated the regulations for the transition to modern management systems in SOEs.

However, with the government's control over wage determination waning, wages of workers in SOEs increased largely, while enterprise profits paid to the government declined dramatically. To address this situation, the notification strengthening macro-control of enterprises' wage bill was published in July 1993 and the rule for the constitution of wage bill was promulgated in November 1995. The government again inserted itself into determining enterprise wage bill and individual wage levels and enforced the unified-management wage system again.

During the 2000s, China's government has promoted establishment and enforcement of labor policy and strengthened its macro-control over the labor market. The 10th five-year plan for labor and social security in January 2002 noted the expansion of wage differentials between monopolistic and competitive sectors of the economy. To settle with the discrepancy, the government established the modern enterprise wage system, set the rate of sustainable wage growth and wage level adjustments based on market mechanisms mainly, and granted autonomy over wage determination to enterprises while permitting workers to participate in wage decisions.

At the same time, the government promoted wage determination based on both market mechanisms and enterprise profit and proposed a collective wage determination system for SOEs and non-SOEs. The government also promulgated the Minimum Wage Act in January 2004 and the notification about improvements in the Minimum Wage Act in June 2007. The Labor Contract Act and the Arbitration and Conciliation of Labor Disputes Act were published in January and May 2008. These laws defined conditions of governing wage determination, employment, and labor disputes.

During the current period of economic transition, in the public sector, the government has reformed wage systems and promoted wage determination based on market mechanisms, but it has retained control over enterprise wage bill and individual basic wage levels. While in the private sector (FEs and PEs), wages are 
primarily decided by market mechanisms. How did wage policies changes affect changes of wage structures in public and private sectors? How did wage policies changes affect changes of wage differentials between the two sectors? The following empirical analysis will answer these questions.

\section{Methodology}

\section{Models}

To measure wage structure differentials, ordinary least squares (OLS) model based on variable means and quantile regression model (Koenker \& Bassett, 1978) derived from the wage distribution are utilized. These models are expressed as equations (1) and (2).

$$
\begin{gathered}
\operatorname{Ln} W_{i}=\alpha+\beta_{p} \mathrm{Pub}_{i}+\beta_{x} X_{i}+u_{i} \\
\operatorname{Ln}_{\theta i}=a_{\theta}+\beta_{\theta(p)} \mathrm{Pub}_{\theta i}+\beta_{\theta i} X_{\theta i}+u_{\theta i}
\end{gathered}
$$

In equations (1) and (2), $i$ denotes workers; $\theta$ is an index indicating the wage percentile; and $\operatorname{Ln} W$ indicates the dependent variable (as a logarithm of the wage rate). $X$ are factors affecting wages and $\beta$ are the estimated coefficients of $X$. Further, $\alpha$ is a constant and $\mu$ is the error term. $\beta_{p}$ and $\beta_{\theta(p)}$ express public-private sector wage differentials.

To clarify differences in wage structure between the two sectors, wage functions by sector groups are estimated. To overcome sample selection bias, the author used the selectivity-bias corrected wage function model (Heckman, 1979) shown by equations (3)-(5). Equation (3) expresses the probability that a worker chooses employment in the public or private sector. ${ }^{3}$ The choice of public sector employment is expressed as $I^{*}$ $=1$ and the choice of private sector employment is expressed as $I^{*}=0 . X$ shows factors identical to those expressed in equations (1) and (2). $Z$ is an identification variable (resembling an instrument variable: IV). Job research routes dummy and the married dummy are used as an identification variable. ${ }^{4}$ Using the estimated results of the distribution function and the density function of the sector selection probability, correct item-named adverse Mill's ratio $(\lambda)$ are calculated. The selectivity-bias corrected wage functions expressed by equations (4) and (5) can be estimated using correct items.

$$
\begin{gathered}
E\left(\varepsilon_{\mathrm{pubi} i} \mid I_{i}^{*}=1\right) \text { or } E\left(\varepsilon_{\mathrm{prii}} \mid I_{i}^{*}=0\right) \\
I_{i}^{*}=b_{i}+\gamma_{x} X_{i}+\gamma_{z} Z_{i}+\varepsilon_{i} \\
\mathrm{Ln} W_{i}=\alpha+\beta_{x} X_{i}+\beta_{\lambda} X_{i}+u_{i}
\end{gathered}
$$

\footnotetext{
${ }^{3}$ Because this paper focuses on wage differentials between the two sectors, it is believed that sample selection bias appears in the worker's choice of public or private sector employment. Therefore, the unemployed are not sampled in this analysis and a binary probability is used.

${ }^{4}$ Job search routes and the married status variables are used as identification variables in this paper for several reasons. First, the government is likely to exert greater influence on labor arrangements in the public sector; so if the worker gained the first job by government mediation, the possibility of working in public sector is relatively higher in research year. Second, according to statistical discrimination theory, in the private sector, if employers consider the average work willingness of single women higher than that of married women, it is thought that the possibility for the married women to be employed is lower than single women. Because gender equality in employment was promoted in the public sector during the planned economy period, it can be thought that the influence of marriage status on public sector employment is smaller.
} 


$$
\operatorname{Ln} W_{\theta i}=a_{\theta}+\beta_{\theta i} X_{\theta i}+\beta_{\theta \lambda} \lambda_{\theta i}+u_{\theta i}
$$

Two decomposition methods are used to estimate determinants of wage differentials. The first is Blinder-Oaxaca decomposition based on variable means. It is expressed by equations (5) and (6). $\bar{X}_{\text {pub }}$ and $\bar{X}_{\text {pri }}$ are variable means of the public and private sectors. $\beta_{\text {pub }}$ and $\beta_{\text {pri }}$ are estimated coefficients. Public-private sector wage differentials are decomposed into two parts as characteristics effects $\left[\beta_{\text {pub }}\left(\bar{X}_{\text {pub }}-\bar{X}_{\text {pri }}\right)\right.$ or $\left.\beta_{\text {pri }}\left(\bar{X}_{\text {pri }}-\bar{X}_{\text {pub }}\right)\right]$ and price effects $\left[\left(\beta_{\text {pub }}-\beta_{\text {pri }}\right) \bar{X}_{\text {pri }}\right.$ or $\left.\left(\beta_{\text {pri }}-\beta_{\text {pub }}\right) \bar{X}_{\text {pub }}\right] .^{5}$ Oaxaca (1973) and Blinder (1973) divided wage differentials into two factors: characteristics effects (differences in human capital endowments) and price effects (differences in wage determination systems, discrimination, and capabilities not presently measurable). The larger the estimated price effect is, the greater is the influence of wage determination systems on wage differentials.

$$
\begin{aligned}
& \operatorname{Ln} \bar{W}_{\text {pub }}-\operatorname{Ln} \bar{W}_{\text {pri }}=\beta_{\text {pub }}\left(\bar{X}_{\text {pub }}-\bar{X}_{\text {pri }}\right)+\left(\beta_{\text {pub }}-\beta_{\text {pri }}\right) \bar{X}_{\text {pri }} \\
& \operatorname{Ln} \bar{W}_{\text {pub }}-\operatorname{Ln} \bar{W}_{\text {pri }}=\beta_{\text {pri }}\left(\bar{X}_{\text {pri }}-\bar{X}_{\text {pub }}\right)+\left(\beta_{\text {pri }}-\beta_{\text {pub }}\right) \bar{X}_{\text {pub }}
\end{aligned}
$$

The second decomposition is based on Machado and Mata (2005). Concrete procedures are as follows:

- First, $n$ samples are randomly selected from the distribution $\left[\theta_{\mathrm{i}}\left(\theta_{1}, \theta_{2}, \theta_{3}, \ldots\right)(i=1, \ldots, \mathrm{n})\right]$ for the public sector datasets;

- Second, $\beta_{\theta(\text { pub })}$ are calculated using the public sector datasets;

- Third, $n$ samples are randomly selected from the datasets distribution $\left[\theta_{\mathrm{i}}\left(\theta_{1}, \theta_{2}, \theta_{3}, \ldots\right)(i=1, \ldots, \mathrm{n})\right]$ of the private sector. Labor productivity characteristics in the private sector are expressed as $X$;

- Fourth, counterfactual public sector wages are calculated as $\operatorname{Ln} \bar{W}_{\text {cpub }}=\hat{\beta}_{\theta(\text { pub })} X_{\theta(\text { pri) }}, i=1, \ldots, n$ (for the density that results in the public sector group, if all covariates parallel the distribution of the private sector), and new datasets are built by pooling the samples of counterfactual public and actual public sector.

This paper also conducts new datasets by pooling the samples of counterfactual private and actual private sector. Using the actual dataset and counterfactual dataset, the effects of the characteristics effect, the price effect, and the residual on wage differentials are calculated according to wage percentiles.

\section{Data}

This study employs two waves of survey data for urban registers: CHIP 1995 and CHIP 2007. These surveys were conducted by the Economic Research Institute of Chinese Academy of Social Sciences (CASS), Beijing Normal University, and the National Bureau of Statistics (NBS) in 1996 and 2008. CHIP 1995 covers 11 provinces and CHIP 2007 covers nine provinces. CHIP 1995 encompasses 27,694 individuals and 5,003 households and CHIP 2007 encompasses 19,748 individuals and 6,931 households. Samples in six provinces (Jiangsu, Anhui, Henan, Hubei, Guangdong, and Sichuan) that were surveyed in both 1995 and 2007 are used. Based on CHIP (1995 and 2007) questionnaires, the samples can be divided into two subsamples: (1) the public

\footnotetext{
${ }^{5}$ It is debated that there exits index number problem in Oaxaca-Blinder model. Estimated results may vary with the kinds of comparison groups utilized. Given space constraints and because the two sets of decomposition results are almost identical, only estimated results using equation (6) are presented in this paper.
} 
sector, which contains SOEs, government organizations, and units related to government organizations (Shiye danwei); (2) the private sector, which contains COEs, FEs, and PEs.

Table 1 displays analysis variables. The logarithm of the wage rate is the dependent variable. Monthly and annual wages include base salary, bonuses, and allowance; financial assets and public transfer payments are excluded. Monthly working hours are calculated using daily working hours and monthly working days. Wage rate calculations are based on total wage and working hours.

Independent variable settings are as follows. In wage functions, ownership dummy variables are divided into four categories: the public sector, COEs, FEs, and PEs (hereafter FE-PE) and others. As indexes of human capital, this paper uses education, tenure, age, an occupational dummy (managerial, technology, clerical, manufacturing, and others), and an industry dummy (agriculture, manufacturing, traffic and communication, commerce, finance-public, and others). It is believed that the effect of work experience on wages includes an age effect and the firm-specific human capital effect results from tenure years increase (Ono, 1989; Ma, 2007; 2009). This paper considers both effects.

Employment status is divided into regular employees (long-term employment), non-regular employees (workers employed under a contact lasting less than one year and non-contract workers), and others. Dummy variables for male, Han race, and the married are used as individual attributes. In addition, it is likely that labor market situations, such as labor supply and demand, and the labor policy implementation, such as minimum wage system are different among provinces (Li \& Ma, 2015). Six province dummies (Jiangsu, Anhui, Henan, Hubei, Guangdong, and Sichuan) are used to control for these regional disparity.

Analysis objects are limited to employees aged from 16 to 59 and the self-employed and family workers are excluded. Sample sizes are 4,285 for CHIP (1995) - 4,679 in the public sector and 1,233 in the private sector and 5,912 for CHIP (2007) - 2,619 in the public sector and 1,666 in the private sector.

Table 1 provides descriptive statistics and shows that worker characteristics are different between public and private sectors, for example, years of schooling and tenure are longer and percentages of managerial and regular employees are higher among public sector workers. Table 1 also shows that wage differentials ( $\operatorname{Ln} \bar{W}_{\text {pub }}-\operatorname{Ln} \bar{W}_{\text {pri }}$ ) rose from 0.284 in 1995 to 0.291 in 2007 .

Figure 2 shows Kernel density distribution of the logarithm of the wage rate in 1995 and 2007. Wage distributions in 1995 and 2007 resemble normal distribution and arithmetic means of the logarithm for the wage rate in the public sector are higher than that in the private sector. In addition, variances increase from 1995 to 2007 in both sectors, which evidence that wage differentials within sectors rose during economic transition period.

Figure 3 displays the logarithm of public and private sector wage rates and wage differentials between the two sectors. Across the all wage percentiles (10th to 90th percentile), public sector wages exceeded private sector wages in 1995 and 2007. Moreover, 1995 and 2007 wage differentials are larger in the low-wage percentiles than that in the middle- and high-wage percentiles. Although wage differentials appear across all the wage percentiles, they are larger for low-wage (i.e., lesser skilled and educated) groups.

\section{How Large Are the Public-Private Sector Wage Differentials?}

Estimated results of the wage function are summarized in Table 2 (OLS model) and Figure 4 (QR model). The main findings are as follows:

(1) First, in 1995, compared with the public sector, the wage level is $22.10 \%$ lower for COEs, but it is 
$14.10 \%$ higher for FE-PE. The wage level in the private sector (FE-PE) is higher than that in public sector. In 2007, the wage level is $8.92 \%$ lower for COEs and 3.95\% lower for FE-PE. These results reveal that wage differentials existed between the public and private sectors in 1995 and 2007, if human capital endowments are held constant. In addition, China's economic transition reduced wage differentials between the public sector and COEs, while wage differentials between the public sector and FE-PE expanded.

(2) Second, Figure 4 displays differentials between the public and private sectors by wage percentiles. The analysis is divided to estimate 1 and estimate 2 according to the variables used. Results of both estimates 1 and 2 for 1995 indicate that the lower the wage distribution is, the larger is the wage differential. While 2007 wage differentials in the middle-wage group are the largest.

Table 1

Description Statistics

\begin{tabular}{|c|c|c|c|c|}
\hline & \multicolumn{2}{|c|}{1995} & \multicolumn{2}{|c|}{2007} \\
\hline & Public sector & Private sector & Public sector & private sector \\
\hline logarithm of wage rate & 1.001 & 0.717 & 2.434 & 2.143 \\
\hline Education & 11 & 9 & 12 & 11 \\
\hline Tenure & 15 & 14 & 18 & 12 \\
\hline Age & 39 & 37 & 37 & 36 \\
\hline Male & $55.8 \%$ & $40.2 \%$ & $50.3 \%$ & $50.4 \%$ \\
\hline Han race & $98.0 \%$ & $98.1 \%$ & $98.8 \%$ & $98.9 \%$ \\
\hline Married & $87.8 \%$ & $85.2 \%$ & $67.8 \%$ & $64.9 \%$ \\
\hline \multicolumn{5}{|l|}{ Occupation } \\
\hline Manager job & $13.7 \%$ & $6.8 \%$ & $11.1 \%$ & $2.5 \%$ \\
\hline Technology job & $23.8 \%$ & $11.1 \%$ & $28.0 \%$ & $19.0 \%$ \\
\hline Clerk job & $23.3 \%$ & $16.0 \%$ & $28.4 \%$ & $17.5 \%$ \\
\hline Manufacturing job & $35.7 \%$ & $56.8 \%$ & $15.6 \%$ & $16.2 \%$ \\
\hline The others & $3.5 \%$ & $9.3 \%$ & $15.9 \%$ & $43.8 \%$ \\
\hline \multicolumn{5}{|l|}{ Employment status } \\
\hline Regular & $98.6 \%$ & $88.9 \%$ & $89.7 \%$ & $62.9 \%$ \\
\hline Non-regular & $1.2 \%$ & $8.4 \%$ & $9.8 \%$ & $36.3 \%$ \\
\hline The others & $0.2 \%$ & $2.7 \%$ & $0.5 \%$ & $0.8 \%$ \\
\hline \multicolumn{5}{|l|}{ Industrials } \\
\hline Agriculture & $2.9 \%$ & $0.9 \%$ & $21.5 \%$ & $39.1 \%$ \\
\hline Manufacturing & $43.9 \%$ & $61.3 \%$ & $18.6 \%$ & $28.9 \%$ \\
\hline Traffic and communication & $4.8 \%$ & $4.2 \%$ & $15.2 \%$ & $16.0 \%$ \\
\hline Commerce & $2.7 \%$ & $2.9 \%$ & $1.1 \%$ & $0.5 \%$ \\
\hline Finance (public) & $19.6 \%$ & $9.1 \%$ & $33.1 \%$ & $9.9 \%$ \\
\hline The others & $26.2 \%$ & $21.6 \%$ & $10.5 \%$ & $5.6 \%$ \\
\hline \multicolumn{5}{|l|}{ Province } \\
\hline Jiangsu & $16.8 \%$ & $26.8 \%$ & $13.3 \%$ & $18.9 \%$ \\
\hline Anhui & $11.7 \%$ & $15.9 \%$ & $17.5 \%$ & $13.1 \%$ \\
\hline Hernan & $16.1 \%$ & $10.7 \%$ & $19.8 \%$ & $11.7 \%$ \\
\hline Hubei & $19.8 \%$ & $11.7 \%$ & $11.2 \%$ & $10.0 \%$ \\
\hline Guangdong & $14.0 \%$ & $18.3 \%$ & $20.7 \%$ & $30.3 \%$ \\
\hline Xichuan & $21.6 \%$ & $16.6 \%$ & $17.5 \%$ & $16.0 \%$ \\
\hline$N$. & 4,679 & 1,233 & 2,619 & 1,666 \\
\hline
\end{tabular}

Source: Estimates based on CHIP 1995 and CHIP 2007. 

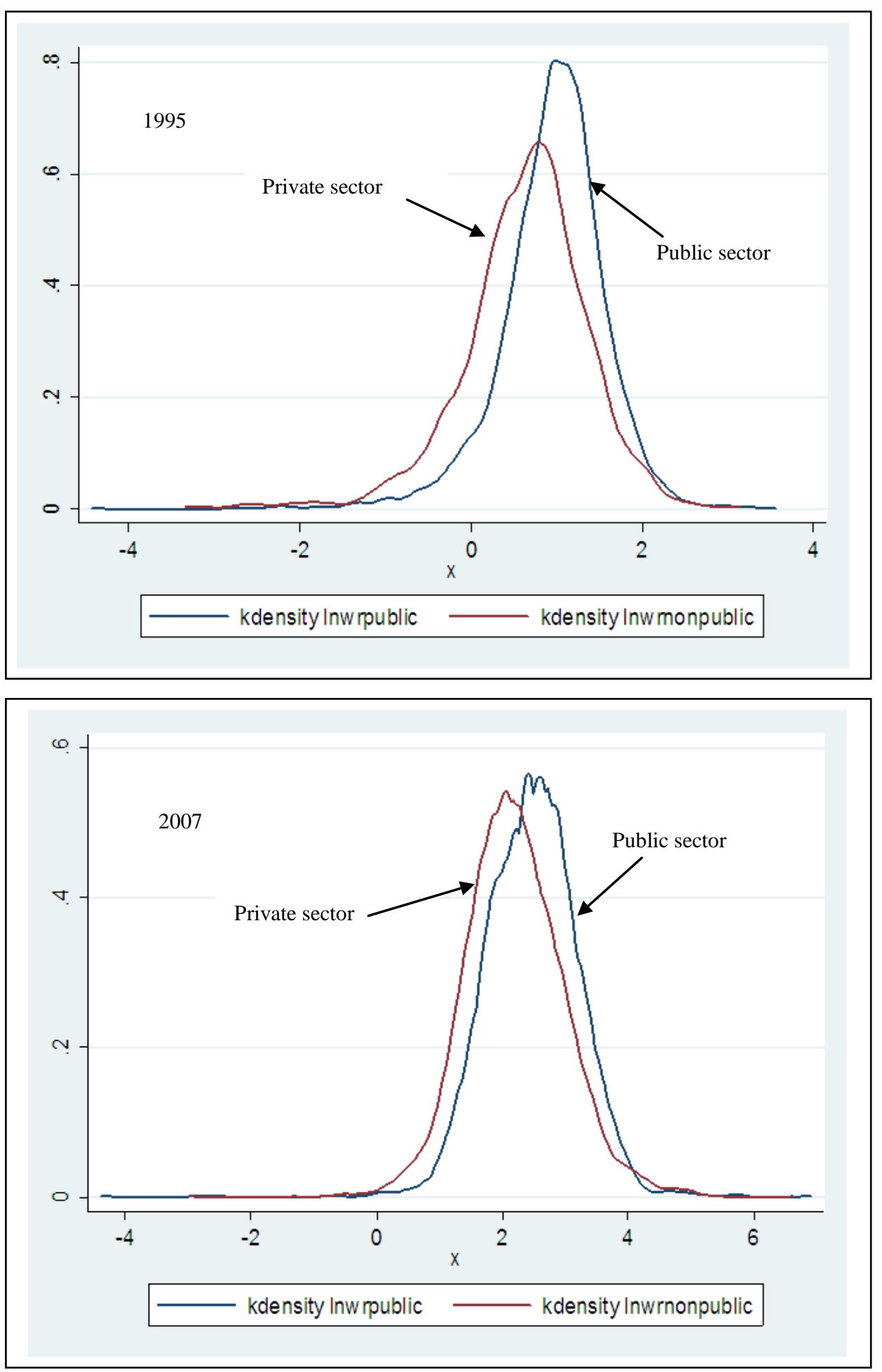

Figure 2. Kernel density distribution in public and private sector wages. 

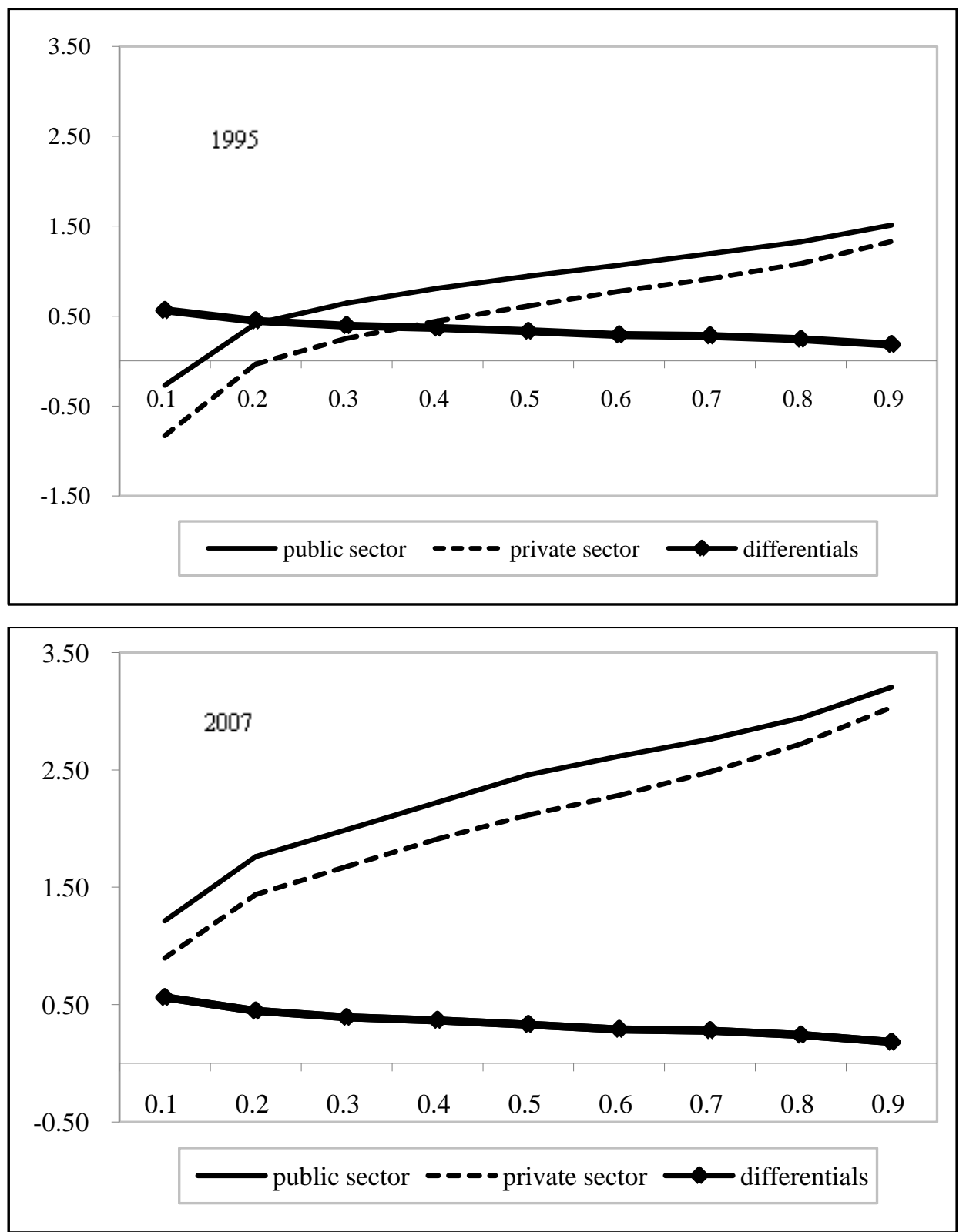

Figure 3. Wage differentials between public and private sectors by wage percentiles. Source: Based on data from Tables 4 to 12 in Chinese Statistical Yearbook 2011. Notes. The values of vertical axis express logarithm of wage rate; differential $=$ logarithm of wage rate in public sector - logarithm of wage rate in private sector.

Table 2

Estimated Results of Wage Differentials Between Public and Private Sectors Wage

\begin{tabular}{lllll}
\hline & \multicolumn{3}{c}{1995} & \multicolumn{2}{c}{2007} \\
\cline { 2 - 5 } & coeff. & $t$ val. & coeff. & -2.35 \\
\hline COE & $-0.2210^{* * *}$ & -10.59 & $-0.0892^{* *}$ & -1.78 \\
FE and PE & $0.1410^{* *}$ & 2.07 & $-0.0395^{*}$ & -6.11 \\
Others & 0.0232 & 0.24 & $-0.2906^{* * *}$ & Pal \\
\hline
\end{tabular}

Notes. $* * * p<0.01$, ** $p<0.05$, and $* p<0.10$; education, tenure, tenure square, age, age square, male, race, the married, occupation dummy, industry dummy, and province dummy are estimated, but these are omitted by publication in the table. Source: Estimates based on CHIP 1995 and CHIP 2007. 

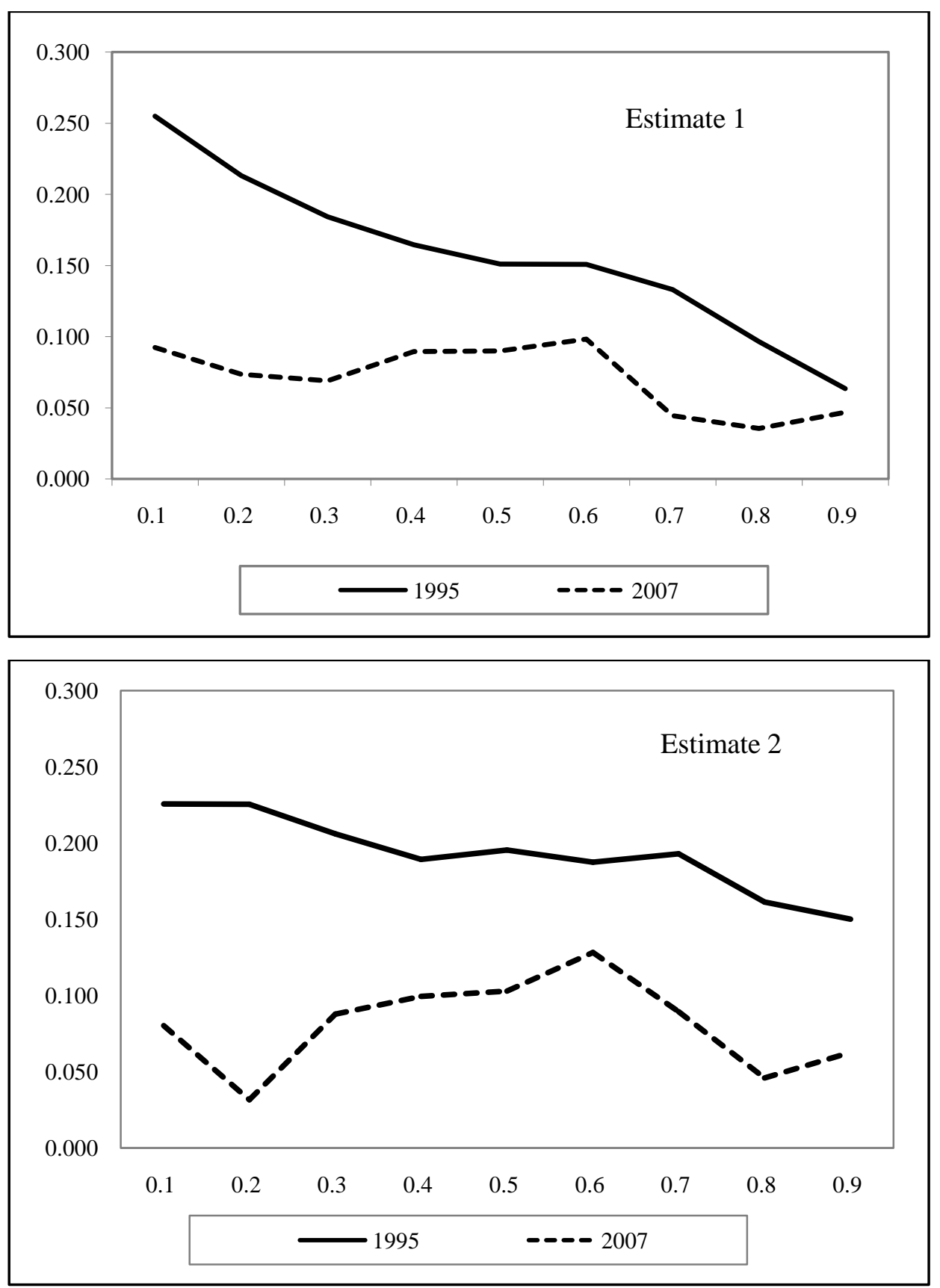

Figure 4. Wage differentials between public and private sectors by wage distribution. Source: Estimates based on CHIP 1995 and CHIP 2007. Notes. Estimate 1: education, tenure, tenure square, age, age square, occupation, and industry dummy are used as variables; estimate 2: added sex, a race, employment status, and province dummy are as variables to estimate 1 .

\section{Are There Wage Structure Differences Between the Public and Private Sectors?}

The estimated results of wage functions based on variable means are reported in Table 3 (OLS model). Following are the main conclusions:

(1) First, rates of return on education in public sector rose from $0.97 \%$ in 1995 to $2.32 \%$ in 2007. In the private sector, they rose from $1.46 \%$ in 1995 to $2.22 \%$ in 2007 . The influence of human capital on wage levels strengthened from 1995 to 2007 in both sectors. 
(2) Second, coefficients of tenure in the public sector rose from 0.0092 in 1995 to 0.0125 in 2007. In the private sector, they rose from 0.0039 in 1995 to 0.0228 in 2007. Market-oriented reforms and firm-specific human capital became more important in the wage determination mechanism.

(3) Third, in 1995 coefficients of age are statistically significant in the public and private sectors, but in 2007 age shows no significant effect on wages in either sector. China's public sector wage reforms might explain these results, for example, the seniority wage system was reformed after the 1980s and the previously described performance payment systems were established for SOEs. Therefore, age became less of a factor in public sector wages, while human capital (education and tenure) were rewarded more in 2007.

Table 3

Estimated Results of Wage Function by Sectors

\begin{tabular}{|c|c|c|c|c|c|c|c|c|}
\hline & \multicolumn{3}{|c|}{1995} & \multicolumn{5}{|c|}{2007} \\
\hline & \multicolumn{2}{|l|}{ Public sector } & \multicolumn{2}{|l|}{ Private sector } & \multicolumn{2}{|l|}{ Public sector } & \multicolumn{2}{|l|}{ Private sector } \\
\hline & coeff. & $t$ val. & coeff. & $t$ val. & coeff. & $t$ val. & coeff. & $t$ val. \\
\hline Education & $0.0097 * *$ & 2.54 & 0.0146 & 1.48 & $0.0232 * * *$ & 5.85 & $0.0222 * * *$ & 4.57 \\
\hline Tenure & $0.0092 * *$ & 2.47 & 0.0039 & 0.44 & $0.0125 * * *$ & 9.23 & $0.0228 * * *$ & 4.00 \\
\hline Tenure square & -0.0001 & -1.38 & -0.0001 & -0.41 & $-7.30 \mathrm{E}-06^{* * *}$ & -10.69 & $-0.0007 * * *$ & -3.59 \\
\hline Age & $0.0481 * * *$ & 5.76 & $0.0931 * * *$ & 4.96 & 0.0058 & 0.61 & -0.0078 & -0.73 \\
\hline Age square & $-0.0005 * * *$ & -4.46 & $-0.0011 * * *$ & -4.64 & -0.0001 & -1.09 & 0.0001 & 0.56 \\
\hline Male & $0.0609 * * *$ & 3.56 & 0.0353 & 0.85 & 0.0003 & 0.01 & 0.0032 & 0.11 \\
\hline Han race & $0.1593 * * *$ & 2.97 & -0.0112 & -0.09 & 0.1527 & 1.27 & 0.1887 & 1.33 \\
\hline Married & $0.1150 * * *$ & 3.46 & -0.0053 & -0.07 & $0.1044 * *$ & 2.10 & 0.0682 & 1.31 \\
\hline \multicolumn{9}{|c|}{ Occupation (Manager job) } \\
\hline Technology job & 0.0281 & 1.06 & 0.0599 & 0.71 & $-0.1781 * * *$ & -3.97 & 0.0301 & 0.31 \\
\hline Clerk job & $-0.0703 * * *$ & -2.63 & -0.0272 & -0.34 & $0.6152 *$ & 1.87 & -0.1842 & -0.42 \\
\hline Manufacturing job & $-0.1717 * * *$ & -6.19 & -0.0965 & -1.30 & -0.4695 & -1.32 & -0.3102 & -0.55 \\
\hline The others & $-0.1481 * * *$ & -3.18 & $-0.1987 * *$ & -2.17 & 0.3543 & 1.10 & -0.4009 & -0.92 \\
\hline \multicolumn{9}{|c|}{ Employment (Regular) } \\
\hline Nonregular & $-0.2481 * * *$ & -3.61 & -0.0554 & -0.81 & $-0.3713 * * *$ & -8.03 & $-0.3823 * * *$ & -11.07 \\
\hline Others & 0.0362 & 0.19 & -0.1185 & -1.08 & -0.2108 & -1.21 & $-0.5403 * * *$ & -3.08 \\
\hline \multicolumn{9}{|c|}{ Industry (Manufacturing) } \\
\hline Agriculture & 0.0336 & 0.74 & $0.3055^{*}$ & 1.68 & $0.9831 * * *$ & 2.98 & -0.0770 & -0.17 \\
\hline $\begin{array}{l}\text { Traffic and } \\
\text { communication }\end{array}$ & $0.1353 * * *$ & 3.82 & $0.1455^{*}$ & 1.70 & $0.9330 * * *$ & 6.11 & -0.1141 & -0.32 \\
\hline Commerce & $-0.1118 * *$ & -2.42 & 0.0124 & 0.12 & $1.5049 * * *$ & 6.47 & 0.0745 & 0.19 \\
\hline Finance $\cdot$ Public & $0.1296 * * *$ & 6.01 & -0.0207 & -0.34 & 0.0909 & 1.34 & -0.0094 & -0.17 \\
\hline The Others & $0.1006 * * *$ & 4.31 & 0.1282 & 1.36 & $0.8485 * *$ & 2.40 & -0.3010 & -0.65 \\
\hline \multicolumn{9}{|l|}{ Province (Jiangsu) } \\
\hline Anhui & $-0.3169 * * *$ & -11.14 & $-0.3500 * * *$ & -6.45 & $-0.1840 * * *$ & -4.03 & $-0.3602 * * *$ & -6.42 \\
\hline Henan & $-0.5119 * * *$ & -17.06 & $-0.5956 * * *$ & -8.30 & $-0.3941 * * *$ & -8.53 & $-0.2876 * * *$ & -4.83 \\
\hline Hubei & $-0.2472 * * *$ & -8.47 & $-0.3854 * * *$ & -5.49 & $-0.2153 * * *$ & -4.22 & -0.0385 & -0.64 \\
\hline Guangdong & $0.3393 * * *$ & 12.31 & $0.5530 * * *$ & 10.25 & $0.4817 * * *$ & 10.72 & $0.3760 * * *$ & 8.42 \\
\hline Sichuan & $-0.2430 * * *$ & -8.92 & $-0.3582 * * *$ & -5.95 & $-0.2716 * * *$ & -5.90 & $-0.2418 * * *$ & -4.73 \\
\hline Adverse Mill's ratio & $-0.2163 * * *$ & -3.22 & $0.2935^{* * *}$ & 3.23 & $-0.1420 * * *$ & -3.38 & 0.0051 & 0.08 \\
\hline Constants & $-0.3517 * *$ & -2.07 & $-1.4250 * * *$ & -3.97 & $1.2410 * * *$ & 3.20 & $2.1645 * * *$ & 4.28 \\
\hline$N$ & 4,670 & & 1,233 & & 2,619 & & 1,666 & \\
\hline$R^{2}$ & 0.3509 & & 0.3140 & & 0.3435 & & 0.3233 & \\
\hline
\end{tabular}

Notes. $* * * p<0.01, * * p<0.05$, and $* p<0.10$. Source: Estimates based on CHIP 1995 and CHIP 2007. 
Table 4 provides the estimated results from the QR model. The wage structures by wage percentiles become apparent as follows:

Table 4

Estimated Results of Wage Function by Sectors and Wage Percentiles

\begin{tabular}{|c|c|c|c|c|c|c|c|c|}
\hline & \multicolumn{2}{|c|}{$10 \%$} & \multicolumn{2}{|l|}{$30 \%$} & \multicolumn{2}{|l|}{$60 \%$} & \multicolumn{2}{|l|}{$90 \%$} \\
\hline & Public & Private & Public & Private & Public & Private & Public & Private \\
\hline \multicolumn{9}{|l|}{1995} \\
\hline Education & $\begin{array}{l}0.0059 \\
(0.86)\end{array}$ & $\begin{array}{l}0.0113 \\
(0.67)\end{array}$ & $\begin{array}{l}0.0143 * * * \\
(4.17)\end{array}$ & $\begin{array}{l}0.0122 \\
(0.94)\end{array}$ & $\begin{array}{l}0.0112 * * * \\
(3.10)\end{array}$ & $\begin{array}{l}0.0171 * \\
(1.84)\end{array}$ & $\begin{array}{l}0.0139 * * \\
(2.20)\end{array}$ & $\begin{array}{l}-0.0100 \\
(-0.56)\end{array}$ \\
\hline Tenure & $\begin{array}{l}0.0041 \\
(0.61)\end{array}$ & $\begin{array}{l}0.0187 \\
(1.22)\end{array}$ & $\begin{array}{l}0.0099 * * * \\
(2.92)\end{array}$ & $\begin{array}{l}0.0092 \\
(0.80)\end{array}$ & $\begin{array}{l}0.0083 * * \\
(2.38)\end{array}$ & $\begin{array}{l}0.0052 \\
(0.64)\end{array}$ & $\begin{array}{l}0.0095 \\
(1.55)\end{array}$ & $\begin{array}{l}-0.0029 \\
(-0.20)\end{array}$ \\
\hline $\begin{array}{l}\text { Tenure } \\
\text { square }\end{array}$ & $\begin{array}{l}-1.48 \mathrm{E}-05 \\
(-0.08)\end{array}$ & $\begin{array}{l}-0.0002 \\
(-0.53)\end{array}$ & $\begin{array}{l}-0.0002 * \\
(-1.68)\end{array}$ & $\begin{array}{l}-0.0002 \\
(-0.63)\end{array}$ & $\begin{array}{l}-0.0001 \\
(-0.80)\end{array}$ & $\begin{array}{l}-0.0002 \\
(-0.70)\end{array}$ & $\begin{array}{l}-0.0002 \\
(-1.05)\end{array}$ & $\begin{array}{l}-0.0002 \\
(-0.44)\end{array}$ \\
\hline Age & $\begin{array}{l}0.0775^{* * * *} \\
(4.89)\end{array}$ & $\begin{array}{l}0.1195^{* * * *} \\
(3.23)\end{array}$ & $\begin{array}{l}0.0475^{* * * *} \\
(6.20)\end{array}$ & $\begin{array}{l}0.1249 * * * \\
(4.92)\end{array}$ & $\begin{array}{l}0.0321 * * * \\
(4.06)\end{array}$ & $\begin{array}{l}0.0479 * * * \\
(2.79)\end{array}$ & $\begin{array}{l}0.0258^{*} \\
(1.85)\end{array}$ & $\begin{array}{l}0.0335 \\
(1.13)\end{array}$ \\
\hline Age square & $\begin{array}{l}-0.0008 * * * \\
(-3.98)\end{array}$ & $\begin{array}{l}-0.0015^{* * * *} \\
(-3.13)\end{array}$ & $\begin{array}{l}-0.0004 * * * \\
(-4.47)\end{array}$ & $\begin{array}{l}-0.0015^{* * *} \\
(-4.66)\end{array}$ & $\begin{array}{l}-0.0003 * * * \\
(-2.89)\end{array}$ & $\begin{array}{l}-0.0005^{* *} \\
(-2.47)\end{array}$ & $\begin{array}{l}-0.0002 \\
(-1.16)\end{array}$ & $\begin{array}{l}-0.0004 \\
(-0.94)\end{array}$ \\
\hline $\begin{array}{l}\text { Adverse } \\
\text { Mill's ratio }\end{array}$ & $\begin{array}{l}-0.4368 * * * \\
(-3.36)\end{array}$ & $\begin{array}{l}0.5538 * * * \\
(3.34)\end{array}$ & $\begin{array}{l}-0.2622 * * * \\
(-4.24)\end{array}$ & $\begin{array}{l}0.1913 \\
(1.54)\end{array}$ & $\begin{array}{l}-0.1734 * * * \\
(-2.74)\end{array}$ & $\begin{array}{l}0.2423 * * * \\
(2.86)\end{array}$ & $\begin{array}{l}0.0366 \\
(0.32)\end{array}$ & $\begin{array}{l}0.4131 * * * \\
(2.71)\end{array}$ \\
\hline Constant & $\begin{array}{l}-1.4561 * * * \\
(-4.66)\end{array}$ & $\begin{array}{l}-2.6945^{* * *} \\
(-3.89)\end{array}$ & $\begin{array}{l}-0.5840 * * * \\
(-3.76)\end{array}$ & $\begin{array}{l}-2.0740 * * * \\
(-4.28)\end{array}$ & $\begin{array}{l}0.1978 \\
(1.23)\end{array}$ & $\begin{array}{l}-0.6543^{* *} \\
(-1.99)\end{array}$ & $\begin{array}{l}0.4901 * \\
(1.71)\end{array}$ & $\begin{array}{l}0.3850 \\
(0.69)\end{array}$ \\
\hline$N$ & 4,670 & 1,233 & 4,670 & 1,233 & 4,670 & 1,233 & 4,670 & 1,233 \\
\hline$R^{2}$ & 0.2304 & 0.2032 & 0.2222 & 0.2125 & 0.2125 & 0.2171 & 0.2278 & 0.2215 \\
\hline \multicolumn{9}{|l|}{2007} \\
\hline Education & $\begin{array}{l}0.0273 * * * \\
(5.22)\end{array}$ & $\begin{array}{l}0.0170 * * \\
(2.41)\end{array}$ & $\begin{array}{l}0.0330 * * * \\
(6.28)\end{array}$ & $\begin{array}{l}0.0253 * * * \\
(4.06)\end{array}$ & $\begin{array}{l}0.0235^{* * *} \\
(6.41)\end{array}$ & $\begin{array}{l}0.0249 * * * \\
(4.48)\end{array}$ & $\begin{array}{l}0.0155^{* * *} \\
(3.09)\end{array}$ & $\begin{array}{l}0.0312 * * * \\
(3.51)\end{array}$ \\
\hline Tenure & $\begin{array}{l}0.0078 * * * \\
(4.69)\end{array}$ & $\begin{array}{l}0.0280 * * * \\
(3.69)\end{array}$ & $\begin{array}{l}0.0148 * * * \\
(8.40)\end{array}$ & $\begin{array}{l}0.0315^{* * * *} \\
(4.34)\end{array}$ & $\begin{array}{l}0.0128 * * * \\
(10.24)\end{array}$ & $\begin{array}{l}0.0290 * * * \\
(4.32)\end{array}$ & $\begin{array}{l}0.0112 * * * \\
(6.75)\end{array}$ & $\begin{array}{l}0.0060 \\
(0.53)\end{array}$ \\
\hline $\begin{array}{l}\text { Tenure } \\
\text { square }\end{array}$ & $\begin{array}{l}-4.96 \mathrm{E}-06^{* * *} \\
(-5.95)\end{array}$ & $\begin{array}{l}-0.0010 * * * \\
(-4.10)\end{array}$ & $\begin{array}{l}-8.49 \mathrm{E}-06 * * * \\
(-9.63)\end{array}$ & $\begin{array}{l}-0.0009 * * * \\
(-4.06)\end{array}$ & $\begin{array}{l}-7.39 \mathrm{E}-06 * * * \\
(-11.84)\end{array}$ & $\begin{array}{l}-0.0008 * * * \\
(-3.79)\end{array}$ & $\begin{array}{l}-6.57 \mathrm{E}-06^{* * * *} \\
(-7.92)\end{array}$ & $\begin{array}{l}-0.0001 \\
(-0.35)\end{array}$ \\
\hline Age & $\begin{array}{l}0.0177 * \\
(1.62)\end{array}$ & $\begin{array}{l}-0.0076 \\
(-0.54)\end{array}$ & $\begin{array}{l}0.0028 \\
(0.24)\end{array}$ & $\begin{array}{l}-0.0066 \\
(-0.47)\end{array}$ & $\begin{array}{l}0.0049 \\
(0.56)\end{array}$ & $\begin{array}{l}-0.0077 \\
(-0.60)\end{array}$ & $\begin{array}{l}-0.0098 \\
(-0.85)\end{array}$ & $\begin{array}{l}-0.0399 * \\
(-1.94)\end{array}$ \\
\hline Age Square & $\begin{array}{l}-0.0002 * \\
(-1.76)\end{array}$ & $\begin{array}{l}4.64 \mathrm{E}-05 \\
(0.27)\end{array}$ & $\begin{array}{l}-0.0001 \\
(-0.44)\end{array}$ & $\begin{array}{l}0.0001 \\
(0.35)\end{array}$ & $\begin{array}{l}-0.0001 \\
(-0.98)\end{array}$ & $\begin{array}{l}0.0001 \\
(0.59)\end{array}$ & $\begin{array}{l}2.51 \mathrm{E}-05 \\
(0.18)\end{array}$ & $\begin{array}{l}0.0004 * \\
(1.69)\end{array}$ \\
\hline $\begin{array}{l}\text { Adverse } \\
\text { Mill's ratio }\end{array}$ & $\begin{array}{l}-0.0707 \\
(-1.37)\end{array}$ & $\begin{array}{l}-0.0876 \\
(-1.03)\end{array}$ & $\begin{array}{l}-0.1059 * * \\
(-1.99)\end{array}$ & $\begin{array}{l}-0.0703 \\
(-0.96)\end{array}$ & $\begin{array}{l}-0.2153 * * * \\
(-5.55)\end{array}$ & $\begin{array}{l}0.0051 \\
(0.08)\end{array}$ & $\begin{array}{l}-0.0786 \\
(-1.48)\end{array}$ & $\begin{array}{l}0.0803 \\
(0.84)\end{array}$ \\
\hline Constant & $\begin{array}{l}0.7448 * * * \\
(2.69)\end{array}$ & $\begin{array}{l}1.9028 * * * \\
(5.97)\end{array}$ & $\begin{array}{l}0.9555^{* *} \\
(2.11)\end{array}$ & $\begin{array}{l}1.4628 * * * \\
(3.48)\end{array}$ & $\begin{array}{l}1.6555^{* * *} \\
(6.26)\end{array}$ & $\begin{array}{l}2.7101 * * * \\
(6.44)\end{array}$ & $\begin{array}{l}1.9268 * * * \\
(6.95)\end{array}$ & $\begin{array}{l}3.3074 * * * \\
(6.57)\end{array}$ \\
\hline$N$ & 2,619 & 1,666 & 2,619 & 1,666 & 2,619 & 1,666 & 2,619 & 1,666 \\
\hline$R^{2}$ & 0.2261 & 0.2100 & 0.2178 & 0.2264 & 0.2261 & 0.2236 & 0.1942 & 0.1812 \\
\hline
\end{tabular}

Notes. $* * * p<0.01$, ** $p<0.05$, and $* p<0.10$; male, race, the married, occupation, industry, and province are estimated, but these are omitted by publication in Table 4; $t$ values are represented in () in Table 4. Source: Estimates based on CHIP 1995 and CHIP 2007.

(1) First, from 1995 to 2007, education return rates increased in wage distributions among the 10th, 30th, 60th, and 90th percentiles in both the sectors. The effect in the public sector is the highest at the 30th percentile in 1995 and 2007. For the private sector, it is the highest at the 60th percentile in 1995 and the 90th percentile in 2007. Education return rates are higher for middle- and high-wage groups in 1995 and 2007. 
(2) Second, compared with 1995, coefficients of tenure increased across the entire wage distribution in both sectors and the statistical significance of tenure became notable in 2007, for example, tenure did not significantly influence private sector wages across all percentiles in 1995, whereas estimated results of tenure were significant at the 10th, 30th, and 60th wage percentiles in 2007. Firm-specific human capital became more important wage determinants for low- and middle-income groups in the private sector.

(3) Third, the influence of age on wage declined from 1995 to 2007. In 1995, in both sectors, age significantly influenced wage at the 10th, 30th, and 60th percentiles. However, in 2007 coefficients of age were insignificant at the 10th, 30th, 60th, and 90th percentiles. Reform of China's seniority wage system had a greater relative effect on low- and middle-wage groups.

\section{What Determinate the Public-Private Wage Differentials?}

Decomposition results using the Blinder-Oaxaca model are summarized in Table 5. Characteristics effects increased from $35.23 \%$ in 1995 to $74.51 \%$ in 2007 . In other words, the price effect declined from $64.77 \%$ in 1995 and $24.59 \%$ in 2007 . These results denoted the greater influence of market mechanisms as a factor in wage differentials, while the influence of institutional factors declined as economic reforms proceeded.

Table 5

Blinder-Oaxaca Decomposition Results

\begin{tabular}{|c|c|c|c|c|}
\hline & \multicolumn{2}{|c|}{ Characteristics effects } & \multicolumn{2}{|c|}{ Price effects } \\
\hline & Values & Percentage & Values & Percentage \\
\hline \multicolumn{5}{|l|}{1995} \\
\hline \multicolumn{5}{|l|}{ Wage differentials } \\
\hline 0.2852 & 0.1005 & $35.23 \%$ & 0.1847 & $64.77 \%$ \\
\hline Education & 0.0292 & $10.24 \%$ & -0.1855 & $-65.04 \%$ \\
\hline Tenure & 0.0086 & $3.03 \%$ & 0.0482 & $16.89 \%$ \\
\hline Age & 0.0122 & $4.30 \%$ & -0.66267 & $-232.34 \%$ \\
\hline Male & 0.0125 & $4.37 \%$ & -0.0094 & $-3.30 \%$ \\
\hline Race & 0.0001 & $0.03 \%$ & 0.1531 & $53.68 \%$ \\
\hline Married & 0.0032 & $1.13 \%$ & 0.1088 & $38.13 \%$ \\
\hline Occupation & 0.0475 & $16.67 \%$ & -0.0641 & $-22.47 \%$ \\
\hline Employment status & 0.0161 & $5.64 \%$ & -0.0032 & $-1.11 \%$ \\
\hline Industry & 0.0278 & $9.75 \%$ & 0.0040 & $1.41 \%$ \\
\hline Province & -0.0567 & $-19.92 \%$ & -0.0140 & $-4.91 \%$ \\
\hline Constant & 0.0000 & $0.00 \%$ & 0.8096 & $283.84 \%$ \\
\hline \multicolumn{5}{|l|}{2007} \\
\hline \multicolumn{5}{|l|}{ Wage differentials } \\
\hline 0.2872 & 0.2073 & $74.51 \%$ & 0.0709 & $25.49 \%$ \\
\hline Education & 0.0268 & $9.64 \%$ & -0.0011 & $-0.39 \%$ \\
\hline Tenure & 0.0845 & $30.37 \%$ & 0.0571 & $20.53 \%$ \\
\hline Age & -0.0056 & $-2.00 \%$ & -0.0055 & $-1.98 \%$ \\
\hline Male & 0.0000 & $0.01 \%$ & -0.0133 & $-4.78 \%$ \\
\hline Race & 0.0000 & $-0.01 \%$ & -0.1122 & $-40.33 \%$ \\
\hline Married & 0.0033 & $1.20 \%$ & 0.0191 & $6.86 \%$ \\
\hline Occupation & -0.0404 & $-14.51 \%$ & 0.406 & $145.93 \%$ \\
\hline Employment status & 0.0741 & $26.65 \%$ & 0.0034 & $1.22 \%$ \\
\hline Industry & 0.1463 & $52.60 \%$ & 0.3212 & $115.45 \%$ \\
\hline Province & -0.0818 & $-29.44 \%$ & 0.0249 & $8.96 \%$ \\
\hline Constant & 0.0000 & $0.00 \%$ & -0.6288 & $-225.99 \%$ \\
\hline
\end{tabular}

Source: Estimates based on CHIP 1995 and CHIP 2007. 
In addition, in 1995, occupation (16.67\%), education $(10.24 \%)$, and industry $(9.75 \%)$ were the most robust factors in characteristics effects; race (53.68\%), marital status $(38.13 \%)$, and tenures $(16.89 \%)$ were the most robust contributors to price effects. In 2007, industries (52.60\%), tenures (30.37\%), and employment status $(26.65 \%)$ were the greatest factors in characteristics effects; occupations (145.93\%), industries $(115.45 \%)$, and tenures $(20.53 \%)$ were in the greatest price effects.

These results reveal that human capital, such as education, tenure, occupation, and industry-specific knowledge, became primary determinants of wage differentials.

Figure 5 displays the decomposition results of wage differentials between China's public and private sectors using the Machado-Mata model. The main findings are as follows.
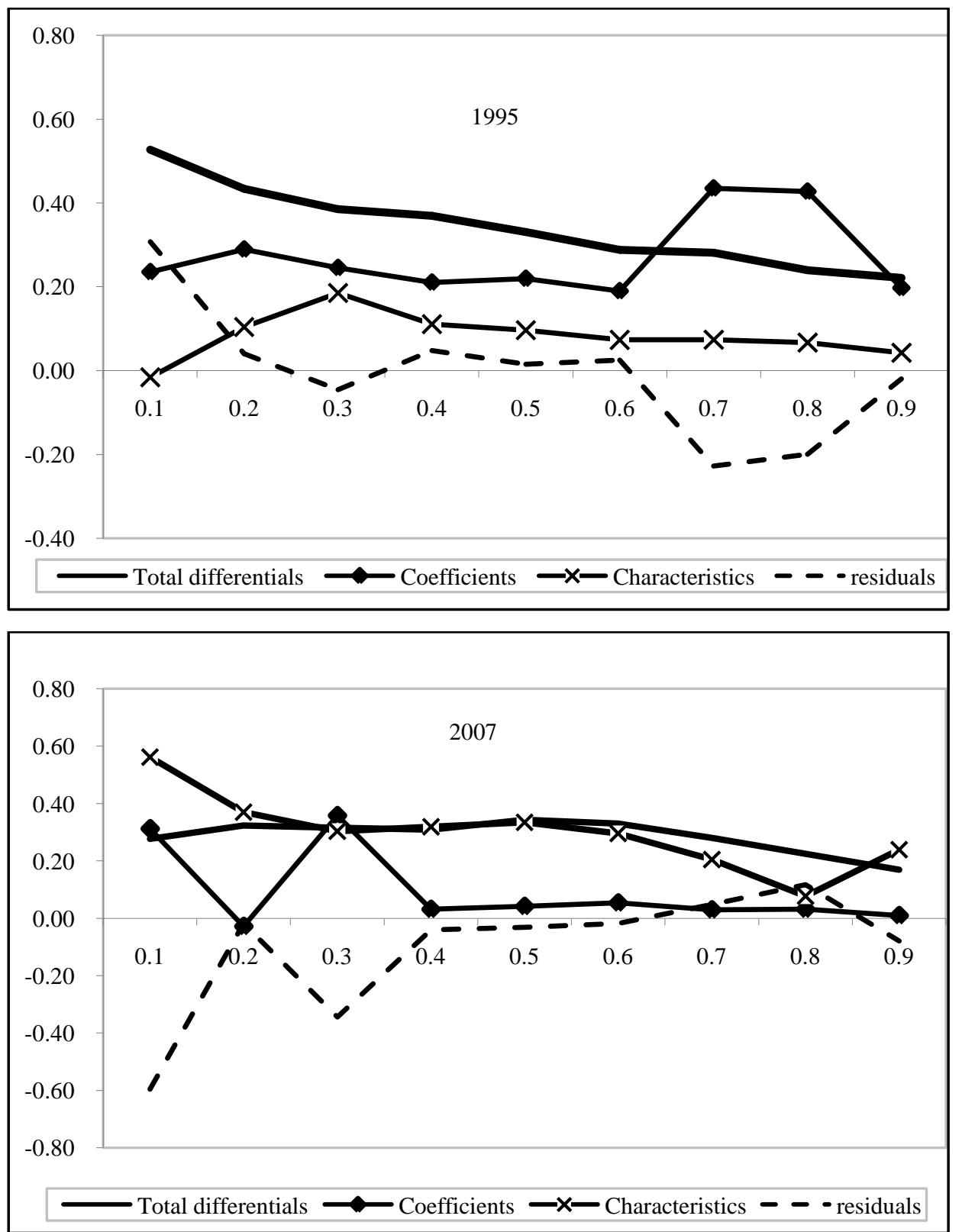

Figure 5. Machado-mata decomposition results of wage differentials between public and private sectors in 1995 and 2007. Source: Estimates based on CHIP 1995 and CHIP 2007. 
(1) First, this paper compares the influences of the coefficient effect, the characteristics effect, and the residual effect on wage differentials by wage distribution. The coefficient effect exhibited the greatest influence in 1995 and the characteristics effect was the greatest in 2007. In sum, differences in the wage determination system primarily explained public and private sector wage differentials in 1995, whereas factor endowments primarily explained wage differentials in 2007.

(2) Second, characteristics effects exerted less influence on the low-wage percentiles (10th percentile) than on the middle- and high-wage percentiles in 1995, whereas they exerted more influence on low-wage percentiles (10th and 20th percentiles) than on middle- and high-wage percentiles in 2007. While coefficient effects exerted less influence on low- and middle-wage percentiles than on high-wage percentiles in 1995, whereas in 2007 their effects on low-wage percentiles (10th and 30th percentiles) were larger than on the middle- and high-wage percentiles. These results indicate that market mechanisms attained greater influence on wages among middle- and high-wage groups along with the progress of economy reforms, whereas the wage system retained influence over low-wage groups. The wage equality system performed during the planned economy period still affected wage determining in the public sector for low-wage groups.

\section{Conclusions}

Under economic transition, China is experiencing major changes in wage policies and wage systems. This paper has empirically assessed how China's wage policy reforms affected wage determination mechanisms. Using the corrected wage function model and decomposition methods, this paper estimated changes in wage structure and determinants of the public-private sector wage differentials in 1995 and 2007. The major conclusions are as follows.

(1) First, holding human capital constant, wage differentials appeared between public and private sectors in China, but they declined from 1995 to 2007. In addition, wage differentials are different through wage distributions, for example, 1995 wage distributions and wage differentials were inversely related. In 2007, wage differentials were greatest among middle-wage groups.

(2) Second, educations and tenures exhibited growing influence on public-private sector wages and the influence of age declined from 1995 to 2007 . These results show that market mechanisms began to function as economy reform progressed.

(3) Finally, results of Blinder-Oaxaca decomposition denote that the characteristics effect increased in influence from $35.23 \%$ for 1995 to $74.51 \%$ for 2007 . During that period, human capital (educations, tenures, occupations, and industries) primarily determined wage differentials. Decomposition results following Machado-Mata reveal that wage determination system primarily explained public-private sector wage differentials in 1995, but differences in factor endowments primarily explained wage differentials in 2007. In addition, results show that market mechanisms gained importance as determinants among middle- and high-wage groups as economy reform progressed, but the wage system retained influence over low-wage groups.

The estimation results pose several policy implications as the following. Even during economic transition, the government partially controlled wage determination systems. As a result, market mechanisms have been unable to function adequately. It is necessary for government to promote further corporate governance reforms (such as privatization of SOEs) and the deregulation of monopolies in the future. Therefore, the influence of market mechanisms on wage determination eventually may become greater and the distortion of the labor 
pricing and labor force allocation should be corrected. In the interim, mitigating income inequality will require active labor policies, such as vocational training policy, the Minimum Wage Act, and unemployment insurance policy. More rigorous studies employing panel data and difference-in-differences (DID) methods to estimate the influence of these wage policies on wage determination are remained for future investigation.

Finally, some research limitations should be pointed out. Although using the employee information from CHIP (1995 and 2007), the determinants of wage differentials between public and private sectors are estimated in this paper. It is thought that other labor demand factors, such as firm productivity, firm HRM (human resource management) systems, and unobservable variables of firms, should affect the wage differentials. Using employer-employee matched data and firm panel data to estimate the wage differential are the future research issues.

\section{References}

Blinder, A. S. (1973). Wage discrimination: Reduced form and structural estimation. Journal of Human Resources, 8, $436-455$.

Bowles, P., \& White, G. (1998). Labor systems in transitional economies: An analysis of China's township and village enterprises (Labor Markets in Transition: International Dimensions, International Review of Comparative Public Policy, No. 10). Stamford, Conn.: JAI Press.

Chen, G., Demurger, S., \& Fournier, M. (2005). Wage differentials and ownership structure of China's enterprises. World Economic Paper, 6, 11-31.

Demurger, S., Fournier, M., Li, S., \& Wei, Z. (2007). Economic liberation with rising segmentation in China's urban labor market. Asian Economic Papers, 5(3), 58-103.

Demurger, S., Li, S., \& Yang, J. (2012). Earning differentials between the public and private sectors in China: Exploring changes for urban local residents in the 2002s. China Economic Review, 23, 138-153.

Dong, X., \& Bowles, P. (2002). Segmentation and discrimination in China's emerging industrial labor market. China Economic Review, 13, 170-196.

Heckman, J. J. (1979). Sample selection bias as a specification error. Econometrica, 47(1), 153-161.

Koenker, R. W., \& Bassett, G. J. (1978). Regression quantile. Econometrica, 46(1), 33-50.

Li, S., \& Ma, X. (2015). Impact of minimum wage on gender wage gaps in urban China. IZA Journal of Labor \& Development, 4(20), doi 10.1186/s40175- 015- 0044-4

Li, S., \& Zhao, R. (2003). The decline of in-kind wage payments in urban China. Journal of Chinese Economic and Business Studies, 1, 245-258.

Lin, Y., Cai, F., \& Li, Z. (1996). Miracle development strategy and economic reform in China. Shanghai: Shanghai People Publishing.

Lu, Z., Wang, X., \& Zhang, P. (2012). Do Chinese state-owned enterprises pay high wage? Economic Research, 3, 28-39.

Ma, X. (2006). Overview and feature of wage systems in modern Chinese enterprises. Labor Studies, 59(10), 19-27.

Ma, X. (2007). An empirical analysis of factor decomposition of differences between Japan and China of male-female wage differentials. The Japanese Journal of Labor Studies, 49(560), 96-107.

$\mathrm{Ma}, \mathrm{X}$. (2009). The enterprise ownership reforms and the change of wage structure in China: Comparison of gender wage profiles differentials by ownership. Journal of Chinese Economic Studies, 6(1), 48-64.

Ma, X. (2014). Wage policy: Economy transition and wage differentials of sectors. In K. Nakagane (Ed.), How did Chinese economy changed? Evaluation of economic systems and policies in post-reform period. Tokyo: Kokusai Shoin Co., Ltd.

Machado, J. A. F., \& Mata, J. (2005). Counterfactual decomposition of changes in wage distributions using quantile regression. Journal of Applied Econometrics, 20(4), 445-465.

Marukawa, T. (2002). Series contemporary Chinese economy 3: Crustal change in the labor market. Nagoya: Nagoya University Publishing.

Meng, X., \& Kidd, M. P. (1997). Labor market reform and the changing structure of wage determination in China's state sector during the 1980s. Journal of Comparative Economics, 25, 403-421.

Nakagane, K. (1999). Economic development in China. Tokyo: Yuhikaku Publishing.

Oaxaca, R. L. (1973). Male-female wage differentials in urban labor markets. International Economic Review, 14(3), 693-709. 
Ono, A. (1989). Labor market and employment practices in Japan. Tokyo: Toyo Keizai Sinhosya Press.

Piore, M. J. (1970). Job and training. In S. H. Beer and R. Barringer (Eds.), The state and the poor (pp. 53-83). Cambridge, MA: Winthrop.

Xing, C. (2006). Wage decision and returns to education by ownerships in China based on quantile regression. World Economic Papers, 1, 1-25.

Xing, C., \& Li, S. (2012). Residual wage inequality in urban China, 1995-2007. China Economic Review, 23, $205-222$.

Yamamoto, T. (2000). Labor economics in modern China: From rational low wage system to modern labor market. Saitama: Sotosya Press.

Ye, L., Li, S., \& Luo, C. (2011). Industrial monopoly, ownership and enterprises wage inequality: An empirical research based on the first national economic census of enterprises data. Management World, 4, 26-36.

Yin, Z., \& Gan, L. (2009). Wage differentials between public and nonpublic sector in China. Economic Research, 4, $129-140$.

Zhang, J., \& Xue, X. (2008). State and non-state sector wage differentials and human capital contribution. Economic Research, 4, $15-25$.

Zhang, Y. (2012). The change of income differentials between public and nonpublic sector in China. Economic Research, 4, 77-88. 